\title{
A Review on Recent Advances of Diagnosis and Monitoring of Different Kinds of Diabetes Mellitus
}

\author{
Ibrahim Bala Baba ${ }^{1}$, Jaya Bharti ${ }^{2}$ \\ 1Department of Medical lab technology, Mewar University Gangrar Chittogarh, Rajasthan, India \\ ${ }^{2}$ Assistant Professor, Department of Medical Lab Technology, School of Health and Allied Sciences, G D \\ Goenka University, Gurugram, Haryana, India
}

\section{Article Info \\ Volume 8, Issue 2 \\ Page Number : 564-570}

\section{Publication Issue}

March-April-2021

\section{Article History}

Accepted : 20 April 2021

Published : 26 April 2021

\section{ABSTRACT}

The increased incidence of non-communicable diseases like Diabetes, with its associated mortality and morbidity amount has contrived the healthcare society to come up with a new way to deal with it. Type 1 Diabetes has usually been the area of importance as the source of the autoimmune reaction, can be refer to many genetic and environmental circumstance. These audits of essay aims to element the origins of Type 1and Type 2 Diabetes and also investigate novel procedure in the examination and monitoring of patients, within the area from conventional blood glucose levels and glycosylated in the level of hemoglobin to genetic markers, hormone levels and autoimmune antibody levels. Monitoring and therapeutic mediation have also proceed from syringe and vial policy of glucose to portable Glucometers, insulin pumps and the artificial pancreas device system. The invention of the Non-invasive Blood glucose monitoring structure is also ongoing. Digitalization in healthcare management has get to the improvement of smart phone operation for the desertification of health data for diabetic patients leading to further global electronic health records that can promote care delivery. The advocacy of self-management with the support of health data operation, increased the consciousness due to diabetic educators, national and global campaigns, and the arrangement of hysterical and psychological support to the patients, has helped to improve consent to fight the disease. The holistic, interdisciplinary and patient centric design used to access the management of Type 1 and Type 2 Diabetes, has shown revised patient result.

Keywords : Type 1 Diabetes, Insulin, Hyperglycemia, Autoimmune disorder, Type 2 Diabetes, Digitization in Healthcare, Genetic defects of the $\beta$-cell 


\section{INTRODUCTION}

Diabetes mellitus is a metabolic disorder that is usually occurring due to defects in insulin secretion, insulin action, or both [1]. Diabetes mellitus is a major public health concern in both developed and developing countries with many medical and economic burdens. The risk factors associated with diabetes include renal disease, adult blindness, impotence, and non-traumatic lower-limb amputation and in some cases, it can lead to death. Despite the challenges in diagnostic and therapeutic options in the treatment of diabetes, there is an improvement in the last two decades. The incidence of diabetes continued to rise in 2007 and the global frequency of diabetes is projected to reach 366 million by the year 2030 [2]. The acute hyperglycemia of diabetes has been associated with some damage, due to the dysfunction, and failure of various parts of the human body, such as the eyes, kidneys, nerves, heart, and blood vessels. The pathogenic processes are involved in the advances of diabetes [1]. Diabetes mellitus is a metabolic disorder, which is associated with an increased risk of micro vascular and macro vascular disease. Its main clinical characteristic is hyperglycemia [1]. The Signs of the deficiency of glucose include polyuria, polyphagia, polydipsia, weight loss, and sometimes blurred vision. The growth and susceptibility of certain infections may also be caused by acute or chronic hyperglycemia. The acute, life-threatening effect of uncontrolled diabetes is an extremely high level of glucose with ketoacidosis or the non-ketosis hyperosmolar syndrome [3]. It took a while for the researchers to discover the mechanisms that lead to hyperglycemia and the effect it has on the human body. The identification of insulin has played a key role in glucose metabolism [4]. Type 1 diabetes was identified in early childhood while type 2 diabetes was discovered in adults. There are two categories of TD1 they include, monogenic diabetes syndromes, which are been found in maturity, and latent
Autoimmune Diabetes that are found in adulthood. In recent years, patients have been exhibiting features of both types of diabetes in the community, making it a high challenge. There is a new experimental technique that shows the measurement of insulin 'impedance' with a peripheral effect of insulin and 'non-insulin-dependent diabetes that lead to the formation of the term "insulin resistance". Further research was been discovered on the role of insulin resistance in cardio metabolic alterations such as dyslipidemia, inflammation, and high blood pressure. During pregnancy, Gestational diabetes starts to raise in blood glucose values above normal but below those conditions of diabetes that occur during the pregnancy. Women, who suffer from gestational diabetes, are at an increased risk of complications during the time of delivery. They are also at increased risk of TD2 in the future [5]. Hemoglobin A1C is a test that stable glycoprotein when glucose binds with hemoglobin $\mathrm{A}$ in the blood by managing the hyperglycemia in uncontrolled diabetic patients.

\section{TYPES OF DIABETES MELLITUS (DM) Type 1(DM)}

In type 1 diabetes $5 \%-10 \%$ of subjects are diagnosed with diabetes [6]. Type 1 usually occurs due to autoimmune destruction of the pancreas in the $\beta$ cells that give responses to the T-cell which mediates the inflammatory response (insulitis) as well as a humeral response (b cells)[7]. The autoantibodies that are present in the pancreatic islet cells are the hallmark of type 1 diabetes (DM), though the presence of the antibodies in the pathogenesis of the disease is not active. Autoantibodies include glutamic acid decarboxylase, islet cell autoantibodies, and autoantibodies to insulin, zinc transporter protein, and protein tyrosine phosphatase [6]. These pancreatic autoantibodies are epitomized by type 1 diabetes (DM) and are been discovered in the serum of the patients, some months or years before the onset of the disease [8] 
Autoimmune type 1 diabetes has a strong human leukocyte antigen(HLA), with linkage to DR and DQ genes. HLA-DR/DQ alleles can be either predisposing or protective [9]. According to International Diabetes Federation (IDF), the number of youth (0-14 years) diagnosed with type 1 diabetes worldwide in 2013 was 497100 (Table 1) and the number of newly diagnosed cases per year was 78900 .

Table1

\begin{tabular}{|c|c|c|c|c|c|c|c|c|}
\hline & \multicolumn{2}{|c|}{$\begin{array}{l}\text { Type } 1 \text { diabetes in children }(0- \\
14 y r)\end{array}$} & \multicolumn{4}{|c|}{ Diabetes in adults (20-79yr) } & \multicolumn{2}{|c|}{$\begin{array}{l}\text { Hyperglycemia } \\
\text { in } \\
\text { pregnancy }(20- \\
49 y \mathbf{y})\end{array}$} \\
\hline Region & 2013 & & 2013 & & & 035 & 2013 & \\
\hline & $\begin{array}{ll}\text { Number } & \text { in } \\
\text { thousands } & \end{array}$ & $\begin{array}{l}\text { Newly } \\
\text { diagnosed in } \\
\text { thousandth }\end{array}$ & $\begin{array}{l}\text { Number } \\
\text { in } \\
\text { millions }\end{array}$ & $\begin{array}{l}\text { Compar } \\
\text { ative } \\
\text { prevale } \\
\text { nce }\end{array}$ & $\begin{array}{l}\text { number } \\
\text { in } \\
\text { million } \\
\mathrm{s}\end{array}$ & $\begin{array}{l}\text { Compara } \\
\text { tive } \\
\text { prevalen } \\
\text { ce }\end{array}$ & $\begin{array}{l}\text { Cases } \\
\text { in } \\
\text { Live } \\
\text { Births } \\
\text { in } \\
\text { Million } \\
\mathrm{s}\end{array}$ & $\begin{array}{l}\text { Compa } \\
\text { rative } \\
\text { prevale } \\
\text { nce }\end{array}$ \\
\hline $\begin{array}{l}\text { Africa } \\
\text { Europe } \\
\text { Middle East } \\
\text { and North } \\
\text { Africa } \\
\text { North } \\
\text { America and } \\
\text { Caribbean } \\
\text { South and } \\
\text { Central } \\
\text { America } \\
\text { Southeast } \\
\text { Asia } \\
\text { Western } \\
\text { Pacific } \\
\text { World }\end{array}$ & $\begin{array}{l}39.1 \\
129.4 \\
64.0 \\
108.6 \\
45.6 \\
\\
77.9 \\
32.5 \\
497.1\end{array}$ & $\begin{array}{l}6.4 \\
20.0 \\
10.7 \\
\\
16.7 \\
7.3 \\
\\
12.5 \\
5.3 \\
78.9\end{array}$ & $\begin{array}{l}19.8 \\
56.3 \\
34.6 \\
\\
36.8 \\
\\
24.1 \\
\\
72.1 \\
138.2 \\
381.8\end{array}$ & $\begin{array}{l}5.7 \% \\
6.8 \% \\
10.9 \% \\
9.6 \% \\
8.2 \% \\
\\
8.7 \% \\
8.1 \% \\
8.3 \%\end{array}$ & $\begin{array}{l}41.5 \\
68.9 \\
67.9 \\
50.4 \\
\\
38.5 \\
\\
123.0 \\
201.8 \\
592.0\end{array}$ & $\begin{array}{l}6.0 \% \\
7.1 \% \\
11.3 \% \\
9.9 \% \\
8.2 \% \\
\\
9.4 \% \\
8.4 \% \\
8.8 \%\end{array}$ & $\begin{array}{l}4.6 \\
1.7 \\
3.4 \\
\\
0.9 \\
\\
0.9 \\
\\
6.3 \\
3.7 \\
21.4\end{array}$ & $\begin{array}{l}14.4 \% \\
12.6 \% \\
17.5 \% \\
10.4 \% \\
11.4 \% \\
\\
25.0 \% \\
11.9 \% \\
14.9 \%\end{array}$ \\
\hline
\end{tabular}

The symptoms of Type 1 diabetes can occur in Type 2 (DM)

some ways like polydipsia, polyuria, enuresis, In type 2 diabetes insulin secretion becomes very lack of energy, extreme tiredness, polyphagia, low with a high demand for insulin due to the sudden weight loss, slow-healing wounds, abrupt destruction of $\beta$ cells [11]. This could recurrent infections, and blurred vision [10]. change some in type 2 diabetes patients by being unable to become dependent on insulin, most 
patients in TDM2 are not dependent on insulin where the secretion in the insulin continues and insulin reduction hardly occurs. Dependence of insulin is one of the main major differences from type 1 diabetes, with the absence of ketoacidosis in most patients of type 2 diabetes and it does not occur in the autoimmune destruction of the $\beta$ cells. Both type 1 and type 2 diabetes have a genetic susceptibility to them, although, type 2 diabetes has a stronger gene, the genes are more characterized in type 1 diabetes (the TCF7L2 gene is strongly associated with type 2 diabetes) [12]. Its diagnosis is usually delayed for some years especially in some countries where regular checkup is not part of the activity. The delay in diagnosis could higher the prevalence of longterm complications in type 2 diabetes patients since hyperglycemia is not treated during this period. The addition to diabetes that has many manifestations of insulin resistance, includes obesity, nephropathy, essential hypertension, dyslipidemia (hypertriglyceridemia, low HDL, decreased LDL particle diameter, enhanced postprandial lipemia, and remnant lipoprotein accumulation), ovarian hyperandrogenism and premature adrenarche, non-alcoholic fatty liver disease and systemic inflammation[13,14]. Among the factors involving in the improvement of insulin resistance, obesity is the most common risk factor that leads to insulin insensitivity and diabetes which involves several mechanisms that engage the pathogenesis of the disease [15]. Obesity- in insulin increases the nutrient flux and energy accumulation in tissues that usually affect cell responsiveness to insulin [16]. The other types of diabetes include Genetic defects of the $\beta$-cell. Many forms of monogenetic diabetes are connecting with the defects in $\beta$-cell function. They are frequently illustrated by the onset of hyperglycemia at an early age before 25years. They are referred to as maturity-onset diabetes of the young (MODY) and are characterized by diminished insulin secretion with minimal or no defects in insulin action [1].Genetic defects in insulin action. There are uncommon causes of diabetes that result from the genetic abnormalities of insulin action. The abnormalities which are associated with the mutations of the insulin receptor may limit from hyperglycemia to acute diabetes. Some Women may be civilized and have enlarged cystic ovaries. In the past, this syndrome was termed type (A) [1]. Diseases of the exocrine pancreas. The process that diffusely injures the pancreas can cause diabetes. These processes include pancreatitis, trauma, infection, pancreatectomy, and pancreatic carcinoma. With exception of cancer that is caused by the damage to the pancreas must be extensive for diabetes to occur; adenocarcinomas involve a small portion of the pancreas that is related to diabetes [1]. Endocrinopathies. The Somatostatinoma and aldosteronoma-induced hypokalemia can cause diabetes, at least in part, by the secretion of insulin inhibition. Hyperglycemia is normally determined by the successful removal of the tumor [1]. Drug- or chemical induced diabetes. Numerous drugs can damage insulin secretion and they may not cause diabetes by themselves, but it can lead to diabetes in individuals with insulin resistance. In most cases, the category of the sequence or relative importance of $\beta$-cell dysfunction and insulin resistance is unspecified [1].

\section{Diagnostic criteria of DM}

The diagnostic criteria for diabetes are listed in Table 2. There are three ways to diagnose diabetes, and this is possible in the absence of unequivocal hyperglycemia which may be confirmed on the previous day, by any of the three procedures given in Table 2. The hemoglobin A1c (A1C) for the diagnosis of diabetes is not endorsed at this time [1].

\section{GDM}

The criteria and diagnosis of abnormal glucose tolerance in pregnancy are those of Carpenter and Coustan [17]. Recommendations from the 
American Diabetes Association's Fourth International Workshop Conference on Gestational Diabetes Mellitus held in March 1997 support the use of the Carpenter/Coustan diagnostic criteria as well as the alternative use of a diagnostic 75-g 2-h OGTT. These criteria are summarized below [1].

1. Symptoms of diabetes plus casual plasma glucose concentration $\geq 200 \mathrm{mg} / \mathrm{dl}(11.1 \mathrm{mmol} /$ 1). Casual is defined as any time of day without regard to time since the last meal. The classic symptoms of diabetes include polyuria, polydipsia, and unexplained weight loss.

Or

2. $F P G \geq 126 \mathrm{mg} / \mathrm{dl}(7.0 \mathrm{mmol} / \mathrm{l})$. Fasting is defined as no caloric intake for at least $8 \mathrm{~h}$.

Or

2-h post-load glucose $\geq 200 \mathrm{mg} / \mathrm{dl}(11.1 \mathrm{mmol} / \mathrm{l})$ during an OGTT. The test should be performed as described by WHO, using a glucose load containing the equivalent of $75 \mathrm{~g}$ anhydrous glucose dissolved in water.

In the absence of unequivocal hyperglycemia, these criteria should be confirmed by repeat testing on a different day. The third measure (OGTT) is not endorsed for routine clinical use.

\section{Testing for GDM.}

The earlier recommendations that include screening for GDM are carried out in all pregnancies. Although certain factors can put women at lower risk for the evolution of glucose intolerance at the time of pregnancy, Pregnant women who succeed in all of these criteria need not be screened for GDM.

This low-risk group include women who;

- have no antiquity of poor obstetric outcome

- have no antiquity of abnormal glucose metabolism

- $\quad$ are 25 years of age

- $\quad$ are normal in body weight
- $\quad$ are not members of an ethnic/racial group with a high prevalence of diabetes (e.g., Hispanic American, Native American, Asian American, African American, Pacific Islander)

have no family history (i.e., first-degree relative) of diabetes

One-step approach. Perform the diagnostic of OGTT without any prior serum or plasma glucose screening. The one-step approach may be cost-effective in highrisk patients or populations (e.g., some Native American groups).

Two-step approach. Perform an initial screening by measuring the plasma or serum glucose concentration $1 \mathrm{~h}$ after a 50-g oral glucose load (glucose challenge test [GCT]) and perform a diagnostic OGTT on that subset of women exceeding the glucose threshold value on the GCT. When the two-step approach is used, a glucose threshold value $>140 \mathrm{mg} / \mathrm{dl}$ (7.8mmol/l) identifies $80 \%$ of women with GDM, and the yield is further increased to $90 \%$ by using a cutoff of $130 \mathrm{mg} / \mathrm{dl}$ (7.2 mmol/l). Diagnostic criteria for the 100-g OGTT are derived from the original work of O'Sullivan and Mahan [18], modified by Carpenter and Coustan and are shown in the top of Table 2.

Table 2. - Diagnosis of GDM with a 100-g or 75-g glucose load

\begin{tabular}{|l|l|l|}
\hline & $\mathrm{mg} / \mathrm{dl}$ & $\mathrm{mmol} / \mathrm{l}$ \\
\hline 100-g Glucose load & & \\
Fasting & 95 & 5.3 \\
1-h & 180 & 10.0 \\
2-h & 155 & 8.6 \\
3-h & 140 & 7.8 \\
75-g Glucose load & & \\
Fasting & 95 & 5.3 \\
1-h & 180 & 10.0 \\
2-h & 155 & 8.6 \\
& & \\
\hline
\end{tabular}


Two or more of the venous plasma concentrations must be met or exceeded

For a positive diagnosis. The test should be done in the morning after an overnight fast of between 8 to $14 \mathrm{~h}$ and at least 3 days of an unlimited diet of $150 \mathrm{~g}$ carbohydrate per day and unregulated physical activity. The patient should remain seated and will be restricted from smoking throughout the test [17].

\section{Management}

Diabetes mellitus is an incurable disease, which has no cure except in actual specific situations. Administration focus on keeping blood sugar levels as close to normal ("euglycemia") as possible, without producing hypoglycemia. This can normally be adept with a weight-reduction plan, workout, and use of good medications (insulin in the case of type 1 diabetes; oral medications, as well as possibly insulin, in type 2 diabetes). The complexity of diabetes is lesser common and lesser serious in people who have well-managed blood sugar levels [19]. The aim of treatment is an HbA1C level of 6.5\%, but it shouldn't be lesser than that and maybe set beyond [19]. Consideration is also given to other health complications that may advance the destructive effects of diabetes. These involve smoking, elevated cholesterol levels, fatness, high blood pressure, and lack of regular workouts. There is particular footwear that is extensively used to reduce the risk of ulceration, or re-ulceration, in at-risk diabetic feet. confirmation for the efficacy of this remains ambiguous, however.[19]

\section{Medication}

Metformin is normally suggested as a first line therapy for type 2 diabetes, as there is genuine evidence that it reduces mortality. Routine use of aspirin, however, has not been found to enhance the consequence in straightforward diabetes. Angiotensin-converting enzyme inhibitors (ACEIs) enhance consequence in those with DM while the homogeneous medications angiotensin receptor blockers (ARBs) do not. Type 1 diabetes is sometimes treated with a mixture of systematic and NPH insulin, or synthetic insulin analogs. Insulin is used in type 2 diabetes, an enduring method is normally added originally, while ongoing oral cure. The amount of insulin will then be increased to effect. In those with diabetes, not too many suggest blood pressure levels below 120/80 mmHg; but, proof only supports less than or equal to someplace between $140 / 90 \mathrm{mmHg}$ to 160/100 mmHg [19].

\section{Conclusion}

Diabetes mellitus has been the outbreak of many centuries and without successful diagnostic procedures at a premature stage, diabetes will continue to arise. This study focuses on the types of diabetes and the successful diagnostic procedure and test to be used for the detection of diabetes and prediabetes. Diabetes is a compound disease with a huge puddle of genes that are required in its evolution. The accurate recognition of the genetic foundation of diabetes potentially gives a requisite tool to enhance diagnoses, therapy, and greater successful genetic support. Moreover, the modern knowledge of the alliance linking the medical genetics and the chronic problem of diabetes will supply an extra advantage to detain or eliminate this problem that foists a huge pressure on patient's quality of life and the significantly arising cost of health-care assistance.

\section{REFERENCES}

[1]. Diabetes care, volume 27, supplement 1, January 2004

[2]. Nguyen Q Nguyen L, Felicetta J. Evaluation and management of diabetes mellitus. Am Health Drug Benefits. 2008; 1: 39-48. 
[3]. Bliss M. WHO technical paper on Diabetes in India- preventable, treatable. J His Med. 1993; 48: 253-254.

[4]. Zaccardi F, Webb D, Yates T. Pathophysiology of type 1 and type 2 diabetes mellitus: a 90-year perspective. Postgrad Med J. 2015; 92: 63-69.

[5]. World Health Organization (2011) Use of Glycated Hemoglobin (HbA1c) in the Diagnosis of Diabetes Mellitus. Abbreviated Report of a WHO Consultation.

[6]. Vermeulen I, Weets I, Asanghanwa M, Ruige J, Van Gaal L, Mathieu C, Keymeulen B, Lampasona V, Wenzlau JM, Hutton JC, Pipeleers DG, Gorus FK. Contribution of antibodies against IA2 $\beta$ and zinc transporter 8 to classification of diabetes diagnosed under 40 years of age. Diabetes Care 2011; 34: 1760-1765 [PMID: 21715527 DOI: 10.2337/dc10-2268]

[7]. Devendra D, Liu E, Eisenbarth GS. Type 1 diabetes: recent developments. BMJ 2004; 328: 750-754 [PMID: 15044291 DOI: 10.1136/bmj.328.7442.750

[8]. Couper J, Donaghue KC. Phases of diabetes in children and adolescents. Pediatr Diabetes 2009; 10 Suppl 12: 13-16 [PMID: 19754614 DOI: 10.1111/j.1399-5448.2009.00574.x]

[9]. American Diabetes Association. Diagnosis and classification of diabetes mellitus. Diabetes Care 2014; 37 Suppl 1: S81-S90 [PMID: 24357215 DOI: 10.2337/dc14-S081]

[10]. International Diabetes Federation. IDF Diabetes Atlas. 6th ed. Brussels, Belgium: International Diabetes Federation, 2013

[11]. Druet C, Tubiana-Rufi N, Chevenne D, Rigal O, Polak M, LevyMarchal C. Characterization of insulin secretion and resistance in type 2 diabetes of adolescents. J Clin Endocrinol Metab 2006; 91: 401-404 [PMID: 16291705 DOI: 10.1210/jc.20051672]

[12]. Saadi H, Nagelkerke N, Carruthers SG, Benedict S, Abdulkhalek S, Reed R, Lukic M, Nicholls MG. Association of TCF7L2 polymorphism with diabetes mellitus, metabolic syndrome, and markers of beta cell function and insulin resistance in a populationbased sample of Emirati subjects. Diabetes Res Clin Pract 2008; 80: 392398 [PMID: 18282631 DOI: 10.1016/j.diabres.2008.01.008]

[13]. Rosenbloom AL, Silverstein JH, Amemiya S, Zeitler P, Klingensmith GJ. Type 2 diabetes in children and adolescents. Pediatr Diabetes 2009; 10 Suppl 12: 17-32 [PMID: 19754615 DOI: 10.1111/j.1399-5448.2009.00584.x]

[14]. Kraemer FB, Ginsberg HN. Gerald M. Reaven, MD: Demonstration of the central role of insulin resistance in type 2 diabetes and cardiovascular disease. Diabetes Care 2014; 37: 1178-1181 [PMID: 24757223 DOI: 10.2337/dc13-2668]

[15]. Ye J. Mechanisms of insulin resistance in obesity. Front Med 2013; 7: 14-24 [PMID: 23471659 DOI: 10.1007/s11684-013-0262-6]

[16]. Otero YF, Stafford JM, McGuinness OP. Pathwayselective insulin resistance and metabolic disease: the importance of nutrient flux. J Biol Chem 2014; 289: 20462-20469 [PMID: 24907277 DOI: 10.1074/jbc.R114.576355]

[17]. Carpenter MW, Coustan DR: Criteria for screening tests for gestational diabetes. Am J Obstet Gynecol 144:768-773, 1982

[18]. O'Sullivan JB, Mahan CM: Criteria for the oral glucose tolerance test in pregnancy. Diabetes $13: 278,1964$

[19]. https://www.researchgate.net/publication/270283 336_Diabetes_mellitus

\section{Cite this article as :}

Ibrahim Bala Baba, Jaya Bharti, "A Review on Recent Advances of Diagnosis and Monitoring of Different Kinds of Diabetes Mellitus", International Journal of Scientific Research in Science and Technology (IJSRST), Online ISSN : 2395-602X, Print ISSN : 23956011, Volume 8 Issue 2, pp. 564-570, March-April 2021. Available at doi : https://doi.org/10.32628/IJSRST218277 Journal URL : https://ijsrst.com/IJSRST218277 